\title{
Ontology Confounds Reproducibility in Ecology and Climate Science ${ }^{1}$
}

\author{
Brent Wilson $^{2}$ and Lee-Ann C. Hayek ${ }^{3}$
}

\begin{abstract}
The ability to reproduce ecological or climate change experiments or quantitative results is a hallmark of science, but not the only one. In addition, a scientist who subsequently examines original research must be able to reproduce the interpretation of the observations. Confidence in both ecology and climate science research is undermined when an a priori interpretation cannot be confirmed. This will happen when an a priori (before investigation) assumption was introduced by the original author(s), even inadvertently, regarding the nature of the universe or a subset of it. Such an assumption is here termed an ontological assumption when it then is treated as invariant; that is, it is not changed as unsupportive evidence, whether positive or negative, is accumulated. It thus conditions the interpretation of observed scientific phenomena. The results of the scientific investigation are therefore interpreted within the framework of this assumption, even though this framework is at variance with actual results obtained.

Recent decades have seen increasing use of paleoclimatic studies as predictors of what will happen as current global climate change unfolds. Here we consider how the results from impact studies of paleoclimatic change on biotic communities have been used as a basis for neoclimatic and ecological research and prediction. We show that in some cases at least the observed results of these paleoclimatic studies were not in accord with the original interpretations, the paleoclimatic workers having held onto unwarranted ontological assumptions in the face of observations to the contrary. This practice is a threat to validity and undermines the applicability of these original paleonvironmental studies to later neoenvironmental work. For example, contrary to expectations, Pleistocene glacial-interglacial cycles did not always impact on community diversity, whether measured by species richness or the information function. Likewise, the quantitative assemblage turnover index (ATI) shows that in the greenhouse world of the Eocene, communities actually were little impacted by lithological changes associated with quantitatively-determined climatic perturbations. We demonstrate that the application of simple statistical measures can draw attention to unwarranted paleoecological ontological assumptions and avoid their being applied inappropriately to neoecological work.
\end{abstract}

Key Words: ontology; reproducibility; foraminifera; Ostracoda; Pleistocene; Paleocene-Eocene thermal maximum; assemblage turnover index; Milankovitch cycles; Ocean Drilling Program; Deep Sea Drilling Program

\section{Introduction: The Nature of Ontology}

Confidence is paramount in science, which advances on a foundation of trusted discoveries. Reproducibility of the interpretation of the observations is vital if one scientist is to have confidence in another's conclusions. However, oftentimes we need to question the assumptions that underlie the presented

\footnotetext{
${ }^{1}$ Received on April 23, 2014. Accepted on April 25, 2014. Last revisions received on May 5, 2014.

${ }^{2}$ Petroleum Geoscience Programme, Department of Chemical Engineering, University of the West Indies, St. Augustine, Trinidad and Tobago. E-mail: brent.wilson@ sta.uwi.edu

${ }^{3}$ Smithsonian Institution, MRC-121, P O Box 37012, Washington DC 20013-7012 USA. E-mail: hayekl@si.edu
}

DOI:10.9784/LEB2(1)Wilson.01

Electronically available on May 16, 2014. Mailed on May 14, 2014. 
interpretation because they involve ontological decisions that are unrecognized. The adoption of quantitative techniques greatly aids in questioning those assumptions.

Ontology is the branch of metaphysics that deals with the nature of being. The term "ontology" refers in philosophy to the manner in which an individual characterises observed phenomena (Libarkin and Kurdziel 2006). Sowa (2010) notes that ontology is a stable pattern of invariant signs that is fossilized in formal theories and does not develop further as each individual interacts with the world and other creatures in it. To adopt an ontological position is to adopt a perspective regarding the nature of the universe and to devise one's interpretations from within that perspective.

An ontological decision is made when a person makes an a prioi (before investigation) decision about the nature of the universe or some subset of it. For example, some communities believe that the Earth and universe were created together only a few thousand years ago, while others believe that the Earth formed over 4 billion years ago (Evans 2001). Those working in macrosociology make the ontological assumption that society is either in balance and functions for the good of all (the functionalist perspective) or that it is rife with class conflict between those who buy and those who sell their labour (the Marxian conflict perspective) (Mooney et al. 2012). Once an ontological decision has been made, the person who has made it then proceeds to interpret the information regarding his/her surroundings, as provided by the senses, within the framework of that decision. All human beings organise their lives and interpretations around ontological assumptions. Some of these are scientifically warranted, as in the macro-sociologists' adoption of contrary perspectives. Others, such as the belief in an Earth only a few thousand years old, are not supported by science. The belief in an ancient Earth is a somewhat flexible assumption as geologists have adjusted their understanding of the solar system's age as evidence has accumulated. Here we are concerned with ontological assumptions that were adopted by paleoclimatic scientists but were not altered as evidence to the contrary was gathered.

\section{Ontological decisions and the use of paleontological data for decision making in the recent and beyond}

In recent years paleoecology has become a powerful resource for ecologists and conservationists, the fossil record containing unique insights into how ecosystems function that cannot be determined by examining solely modern systems. The fossil record, for example, can provide a 'deep time' perspective on the response of communities to climate change.

Here we consider results from impact studies of paleoclimatic change on biotic communities used as a basis for neoclimatic and ecological research and prediction, and show that results are not in accord with interpretations. First we consider the world during an icehouse state and examine glacial/interglacial 
transformations in the sedimentary, lithological and biotic fossil record as indicators of recent ecological changes with recent climate change. Then we examine as an exemplar the ontologically predicted relationship between climate, diversity and lithology in a greenhouse world, Lower Eocene section. Our objective is to instil a cautionary note for parallels with recent events into the uncritical use of paloecological results based upon inherent ontological assumptions

\section{The impact of ontological decisions on the interpretation of the biotic impact of climate change during the Pleistocene}

Ever since Fourier (1824), Croll (1867, 1875) and Milankovitch (1930) recognized astronomically-forced climate fluctuations, there has been an ontological assumption that Pleistocene glacial-interglacial cycles greatly impacted global biota (e.g. Geikie 1874, Segota 1967, Fleming 2006), whether comprising terrestrial (e.g. Astorga and Pino 2011, Böcher 2012) or marine (e.g. Aguirre et al. 2011, Liu et al. 2011) organisms, including abyssal foraminifera (e.g. Schnitker 1974) and ostracodes (e.g. Alvarez Zarikian et al. 2009). Foraminifera are minute unicellular protists with fossilizable tests (Haynes 1981, Murray 2006) and ostracodes are microscopic, bivalved crustaceans (Horne et al. 2013), both of which are useful in assessing ancient (e.g. Smart 2003) and modern (e.g. Schönfeld et al. 2012) environmental and climate changes.

Some authors have with apparent success sought to distinguish glacial and interglacial assemblages of foraminifera or ostracodes. Phleger et al. (1953) noted the presence in North Atlantic piston cores of "layers of [foraminiferal] faunas normal for their latitude alternating with faunas typical of a higher latitude." Streeter (1973) found that Atlantic benthonic foraminifera at depths $>2500 \mathrm{~m}$ varied greatly over the last $150 \mathrm{ka}$. He suggested that this arose because of depression and elevation of faunas through a depth range of several hundred meters between glacials and interglacials.

However, paleontological research has not been completely successful in distinguishing glacial and interglacial assemblages (Roy et al., 1996). For example, although Streeter and Lavery (1982) recorded that uppermost Pleistocene foraminiferal faunas in cores from the western North Atlantic slope and rise were dominated by Uvigerina, but that Hoeglundina dominated in the Holocene, they further suggested that this faunal transition was diachronous, occurring at $\sim 12 \mathrm{ka}$ at $3,000 \mathrm{~m}$, but at $\sim 8 \mathrm{ka}$ at $4,000 \mathrm{~m}$. Thus, one cannot (a) characterise either assemblage as being definitely glacial or interglacial in origin and/or (b) use the change in the fauna to correlate the sedimentary successions at different paleodepths.

Other studies, although they have made an ontological decision that there must have been glacial-interglacial regime shifts (i.e., fluctuations between steady ecological states that are not readily reversible (Genkai-Kato 2007)), have presented unconvincing evidence of distinct glacial and interglacial 
communities. Aksu et al. (1992) found glacial-interglacial, community-level regime shifts in coccoliths and dinoflagellates in the NE Labrador Sea but less persuasive evidence of regime shifts among planktonic foraminiferal assemblages, which were dominated by the polar-water indicator Neogloboquadrina pachyderma (Ehrenberg) with sinistral coiling. The authors wrote that $N$. pachyderma sinistral dominated most interglacial faunas before 0.5 $\mathrm{Ma}$, which were therefore assumed to be "similar to those found in the glacial stages." Didie and Bauch (2000) suggested that the ostracode fauna in the upper Pleistocene of Rockall Plateau, North Atlantic, fluctuated between a "mainly" interglacial Henryhowella-Pelecocythere-Echinocythereis-CytherellaBradleya-Aversovalva-Eucytherura assemblage and a glacial AcetabulastomaRhombobythere-Bythoceratina-Polycope-Pseudocythere assemblage that they wrote "appears" to be restricted to peak glacial periods. Hunt et al. (2005) made the ontological assumption that there should be glacial-interglacial contrasts in benthonic foraminiferal species richness (S) across glacialinterglacial cycles over the past $130 \mathrm{kyr}$ in the deep-sea throughout the Atlantic and Pacific Oceans. However, they found statistically significant $(\mathrm{p}<0.05)$ correlations between oxygen isotope-derived temperatures and $\mathrm{S}$ in only four of ten cores. Martinez et al. (2007) suggested that in western Caribbean Sea, Middle-Upper Quaternary planktonic foraminifera in the Sea, diversity measured using the information function $H=-\Sigma p_{i} \cdot \ln \left(p_{i}\right)$, where $p_{i}$ is the proportional abundance of the $i$ th species] was during glacials depressed by the development of a deep thermocline. However, their data show that $\mathrm{H}$ did not differ between the interglacial marine isotope stage (MIS) 11 and MIS 12, and was lower during the interglacial MIS 13 than in the adjacent glacials MIS 12 and MIS 14.

Some authors, seemingly having consciously avoided making an a priori assumption that there must have been distinct glacial and interglacial assemblages in all environments, have avoided stressing glacial-interglacial patterns and so found unexpected if subtle patterns (Roy et al., 1996). For example, Sen Gupta et al. (1982) examined Late Quaternary benthonic foraminifera in three cores taken near $2000 \mathrm{~m}$ from the eastern Caribbean Sea. They found that the assemblage changed only subtly at glacial-interglacial boundaries based on Globorotalia menardii (d'Orbigny, 1826) (for details, see Ericson and Wollin 1956, 1968; Martin et al. 1990). While not finding distinct glacial and interglacial communities, Sen Gupta et al. (1982) instead recorded some species-level contrasts, noting that Nuttallides umbonifera (Cushman, 1933), Bulimina buchiana Carpenter, Parker, and Jones, 1862 and Chilostomella oolina Schwager, 1878 were more common the last two glacials that in interglacials. Wilson (2012) used SHE analysis (Hayek and Buzas 1997) for the identification of abundance biozones (SHEBI - Buzas and Hayek 1998) when examining planktonic foraminiferal associations in three piston cores from the northeastern Caribbean Sea, and found that there was no relationship between 
abundance biozones and those glacial-interglacial boundaries based on Globorotalia menardii. The succession of abundance biozones differed between the three cores, although taken only $\sim 150 \mathrm{~km}$ apart and from similar water depths, indicating that the region is one of considerable oceanographic complexity. This is reflected in the distinct benthonic foraminiferal associations found in these cores (Wilson 2011), which, once again, do not show any marked glacial-interglacial contrasts (Wilson 2008) but show that the organic flux in the northeast Caribbean Sea decreased gradually through the Late Quaternary. Wilson (2013) recorded a major regime shift during MIS 8-9 in the Upper Quaternary of ODP Hole 1006A (Santaren Channel, offshore western Bahamas), but otherwise found only weak evidence of Milankovich cycles, Globocassidulina subglobosa (Brady, 1881) and Cibicidoides aff. C. io (Cushman, 1931) being smaller assemblage components during some glacial MISs. However, the percentages of these species were not significantly correlated with one another. Wilson (2014), following an examination of benthonic foraminifera in the abyssal ODP Hole 994C (Blake Ridge, western Atlantic Ocean) using SHEBI, concluded that "community restructuring had no significant relationship to paleoclimatic events, including glacial cycles and terminations."

Hayek and Wilson (2013) developed a simple statistical measure, the assemblage turnover index (ATI), and showed that ATI in ODP Hole 994C peaked primarily during the transgressions associated with Pleistocene glacial terminations. They concluded that "the current inability to detect glacialinterglacial contrasts in general appears to arise because not all sites show marked changes in community composition at the species level at glacialinterglacial boundaries." This is apparently because the onset of glacial conditions is a protracted process while deglaciation occurs rapidly (see Berger 2008, Figure 1). The slow onset induces only low levels of assemblage turnover in abyssal foraminiferal assemblages, while the rapid warming and influx of freshwater during deglaciation provoke a major and rapid restructuring of the community. In addition, Hayek and Wilson (2013, Table 3) showed that the species affected by the turnover differed between the peaks in ATI, such that one would not expect to find identical faunas in all glacials or all interglacials. This implies that glacial and interglacial conditions act as attractors comparable to a butterfly-shaped representation of the Lorenz attractor of Chaos Theory (Figure 1), in which minor differences in the initial conditions of any two or more systems (such as at, say, the onset of glacials or interglacials) prevent the perfect convergence of those systems onto a point representing a single state (Schaffer 1985, Holden and Muhamad 1986, Chang 2013). Thus, the details of the abyssal foraminiferal assemblage in one glacial cannot be predicted from those of the assemblage in the preceding glacial. This shows that the precise development of the modern assemblage cannot be modelled using the Pleistocene record, which can only be used to suggest general trends. 


\section{Ontological decisions and interpretations of the impact of Early Eocene climate change}

Here we present a second example of the interface between paleoecology and ecology. This one is from the greenhouse world of the Early Eocene and is for comparative use with present day climate changes under the global warming documented to have occurred over recent past centuries.

Recent years have seen increased interest in Early Eocene paleoclimates (Kaiho 1991, Katz and Miller 1991, Thomas 1992, Kaiho 1994, Thomas and Shackleton 1996, Lourens et al. 2005, Higgins and Schrag 2006, Miller et al. 2008, D'haenens et al. 2012, Galeotti et al. 2012). A major warming at the Palaeocene-Eocene boundary (the Paleocene-Eocene thermal maximum, PETM, about 55 myr) has been identified as being the single largest, well-documented warming event in the history of the Earth (Zachos et al. 2007). It was accompanied by a major carbon isotope excursion (CIE - Kennett and Stott 1991) and is thought to have had considerable biotic impacts (Sluijs et al. 2007).

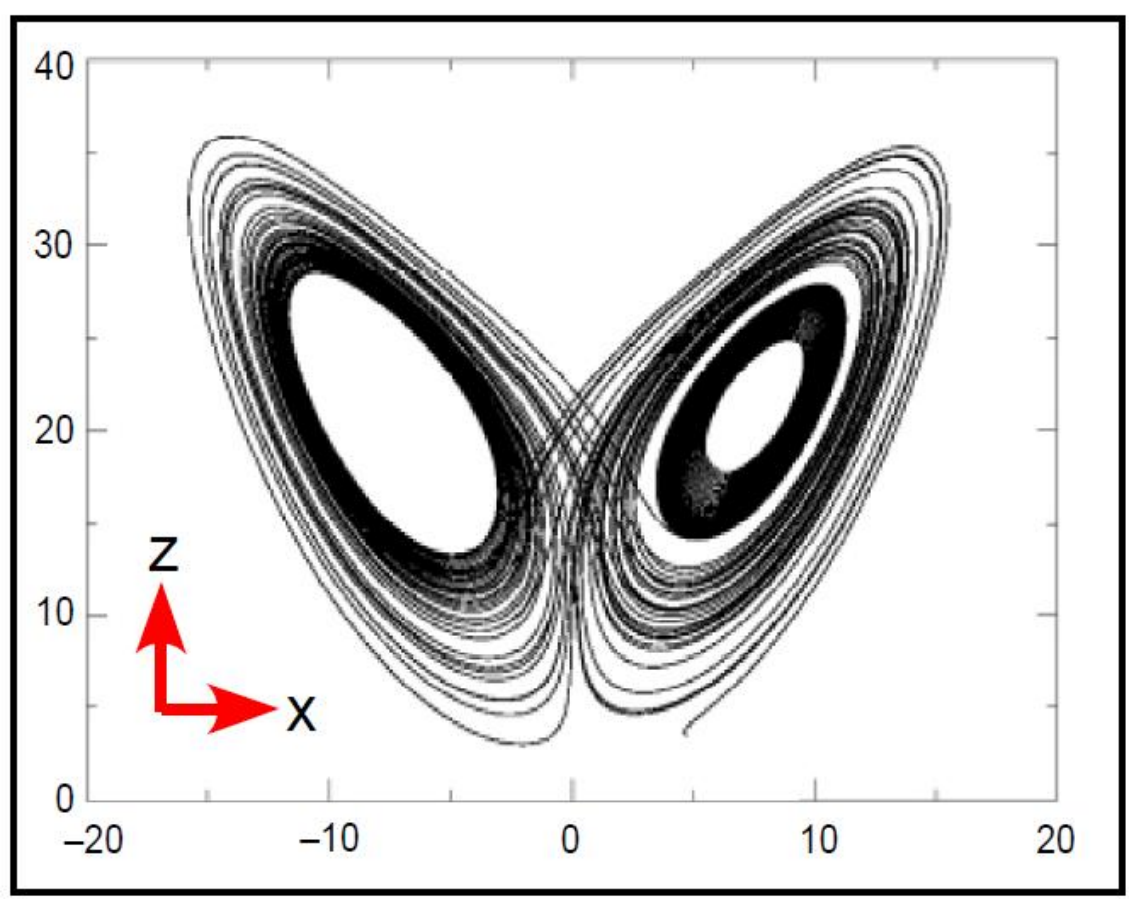

Figure 1. The butterfly-shaped Lorenz attractor of Chaos Theory shown in the $\mathrm{x} / \mathrm{z}$ plane.

It is, however, only the most extreme of a series of such events during the Late Palaeocene and Early Eocene (Thomas and Zachos 2000). Oxygen and carbon stable isotope records show quantitatively that during the PETM global 
temperature rose by $>5-8^{\circ} \mathrm{C}$ in $<10 \mathrm{kyr}$ and remained high for some tens of thousands of years before gradually abating. Ocean acidification and carbonate dissolution during the PETM led to the deposition at bathyal and abyssal depths of condensed, clay rich Palaeocene-Eocene boundary sections (Thomas et al. 1999, Takeda and Kaiho 2007, Zachos et al. 2007). Similar clay-rich horizons of Early Eocene age have been ascribed to other hyperthermal events. Lourens et al. (2005) found a carbonate-poor, red clay (the Elmo horizon) in deep-sea cores from Walvis ridge, Antarctica, and estimated it to have been deposited $\sim 2$ million years after the PETM. The Elmo horizon being coincident with carbon isotope depletion events elsewhere, Lourens et al. (2005) suggested it to be a second global thermal maximum. It may thus be equivalent to the Eocene Thermal Maximum 2 (ETM2; 53.7 Ma) recorded by Stap et al. (2010) from Ocean Drilling Program Sites 1265, 1267, and 1263 (Walvis Ridge, SE Atlantic Ocean). Cramer et al. (2003) found numerous rapid (40-60 kyr duration) negative excursions of up to $1 \%$ in carbon isotope records for upper Paleocenelower Eocene sections at widely separated (North Atlantic, Pacific and Southern Ocean) Ocean Drilling Program and Deep Sea Drilling Project Sites coincident with maxima in the Earth's orbital eccentricity. This resulted in high-amplitude variations in insolation due to forcing by climatic precession. These they used to correlate the four sites, labelling them events A-L, with paired events being individually identified with a 1 or 2 after the letter. Lourens et al. (2005) concluded the Elmo horizon to be correlative with event $\mathrm{H} 1$ of Cramer et al. (2003).

However, sedimentological evidence of all these events is not found everywhere. The Shipboard Scientific Party for Ocean Drilling Program (ODP) Leg 207, located on the Demerara Rise off Surinam, South America (Shipboard Scientific Party 2004), found a single clay rich horizon in ODP Hole 1259B that they ascribed to the PETM. However, their visual core descriptions for this and the accompanying Holes 1259A and 1259C do not show any other clay rich horizons that may be correlated with A-L of Cramer et al. (2003). D'haenens et al. (2012) found five marl (calcareous claystone) beds within an otherwise chalky early Eocene section at DSDP Site 401 (Bay of Biscay - NE Atlantic), and labelled these $\alpha$ though $\varepsilon$ (oldest to youngest). These clay-enriched levels they found to correspond to negative $\delta^{13} \mathrm{C}$ and $\delta^{18} \mathrm{O}$ bulk-rock excursions indicative of injections of ${ }^{12} \mathrm{C}$-enriched greenhouse gasses and small rises in temperature. They did not, however, correlate these with any of events A-K of Cramer et al. (2003).

Where sedimentological evidence is found, it has not always been noted to be reflected in the biota. Wing and Harrington (2001) examined pollen in a 900 $\mathrm{m}$ section of the terrestrial Fort Union and Willwood Formations in the Bighorn Basin (NE Wyoming) that spans the Upper Paleocene and Lower Eocene. They found that there were no last appearances of common taxa at the Paleocene/Eocene boundary, and concluded on this basis that the modest level 
of floral change coincident with the PETM contrasts with the marked coeval taxonomic turnover and ecological rearrangement of North American mammalian faunas. They suggested that the faunal change probably resulted from faunal migration across Arctic land bridges that became habitable during the PETM, but that climatically sensitive plants were unable to migrate across these bridges. Thus, primary cause of terrestrial biotic change across the Paleocene/Eocene boundary was in Wyoming the result of interactions between immigrant and native taxa, not climate change directly. They did not, however, examine in detail the changes in proportional abundances of common species across the Paleocene-Eocene boundary.

The PETM has been identified as causing a major extinction among bathyal and abyssal foraminifera (30-50\% of species; see Thomas 1992). Lourens et al. (2005) found that in the Elmo horizon benthonic foraminiferal species richness is low and assemblages are dominated by diminutive Nuttallides truempyi and Abyssamina spp. This contrasts with Wilson's (2014) finding that in the Upper Quaternary of ODP Hole 994C, benthonic foraminiferal diversity measured using the information function $\mathrm{H}$ was negatively correlated with palaeotemperature estimated from oxygen isotope ratios. This suggests that diversity may be depressed by stresses due to both hypothermal and hyperthermal events. Thus, those working on neoecology cannot yet make conclusive predictive statements concerning biotic change that will result solely from regarding impending events.

\section{Using the assemblage turnover index (ATI) to sidestep ontology}

To avoid the impact of ontological decisions on interpretations of the impact of palaeoclimate change on biotic assemblages, Hayek and Wilson (2013) introduced two statistical indices to assess assemblage turnover, the assemblage turnover index (ATI) and the Conditioned on Boundary Index (CoBI) (See Appendix 1). Their use makes the statistical analyses of vectors of proportional data objective. They are here applied to an exemplar of foraminifera, but can be applied to any variable for which a series of proportional data over time are available (e.g. oxygen isotopes in an ice core, carbon isotopes in a sedimentary rock succession).

D'haenens et al. (2012) made the ontological assumption that there must be changes in the foraminiferal fauna associated with the five Early Eocene marl beds in the chalky section at DSDP Site 401. They concluded that the foraminiferal record shows increased relative abundances of oligotrophic taxa (e.g. Nuttallides umbonifera) and a reduction in the abundance of buliminid species followed by an increase of opportunistic taxa (e.g. Globocassidulina subglobosa and Gyroidinoides spp.) coeval with several (but not all) of these lithological, presumably hyperthermal events. ATI shows that some marl levels (LATI-2 and LATI-4) coincided with low values of ATI ${ }_{\mathrm{s}}$, but this was not true of all; $\mathrm{ATI}_{\mathrm{s}}$ was low at the base of LATI-6 but was higher within it, while LATI- 
8 entrained several peaks at which $A T I_{s}>(\bar{x}+\sigma)$. Thus, peaks in otherwise low background turnover as shown by $\mathrm{ATI}_{\mathrm{s}}$ do not coincide with changes in lithology and the marl levels do not all show either the same values or patterns of $\mathrm{ATI}_{\mathrm{s}}$ (Figure 2).

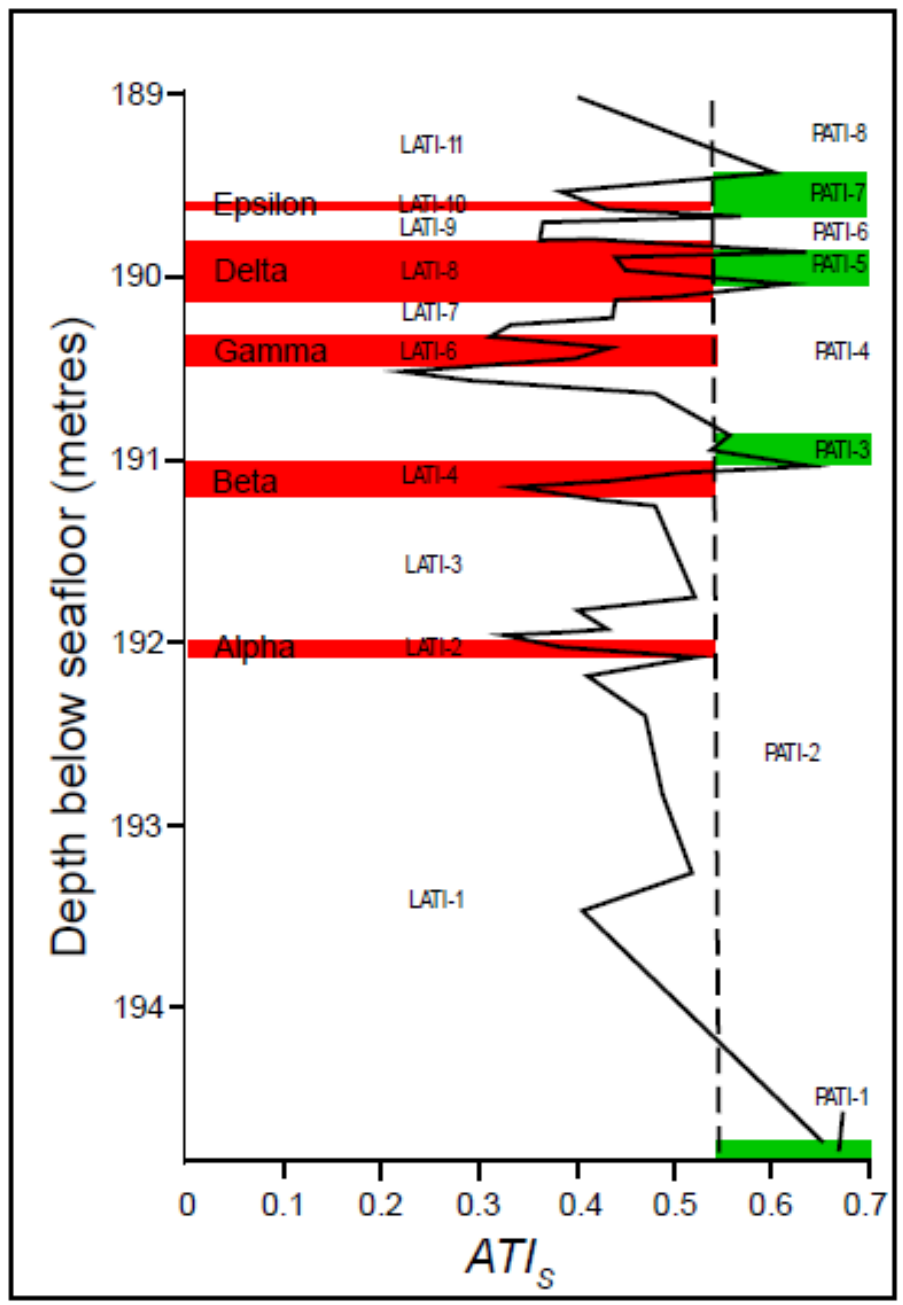

Figure 2. The between sample assemblage turnover index $\left(\mathrm{ATI}_{\mathrm{s}}\right)$ for benthonic foraminifera in the Lower Eocene at DSDP Site 401 (Bay of Biscay - NE Atlantic), data from D'haenens et al. (2012). Red indicates marl beds $\alpha-\varepsilon$, green indicates oddnumbered peak bounded assemblage turnover intervals (PATIs). Dashed vertical line marks mean ATIs. 


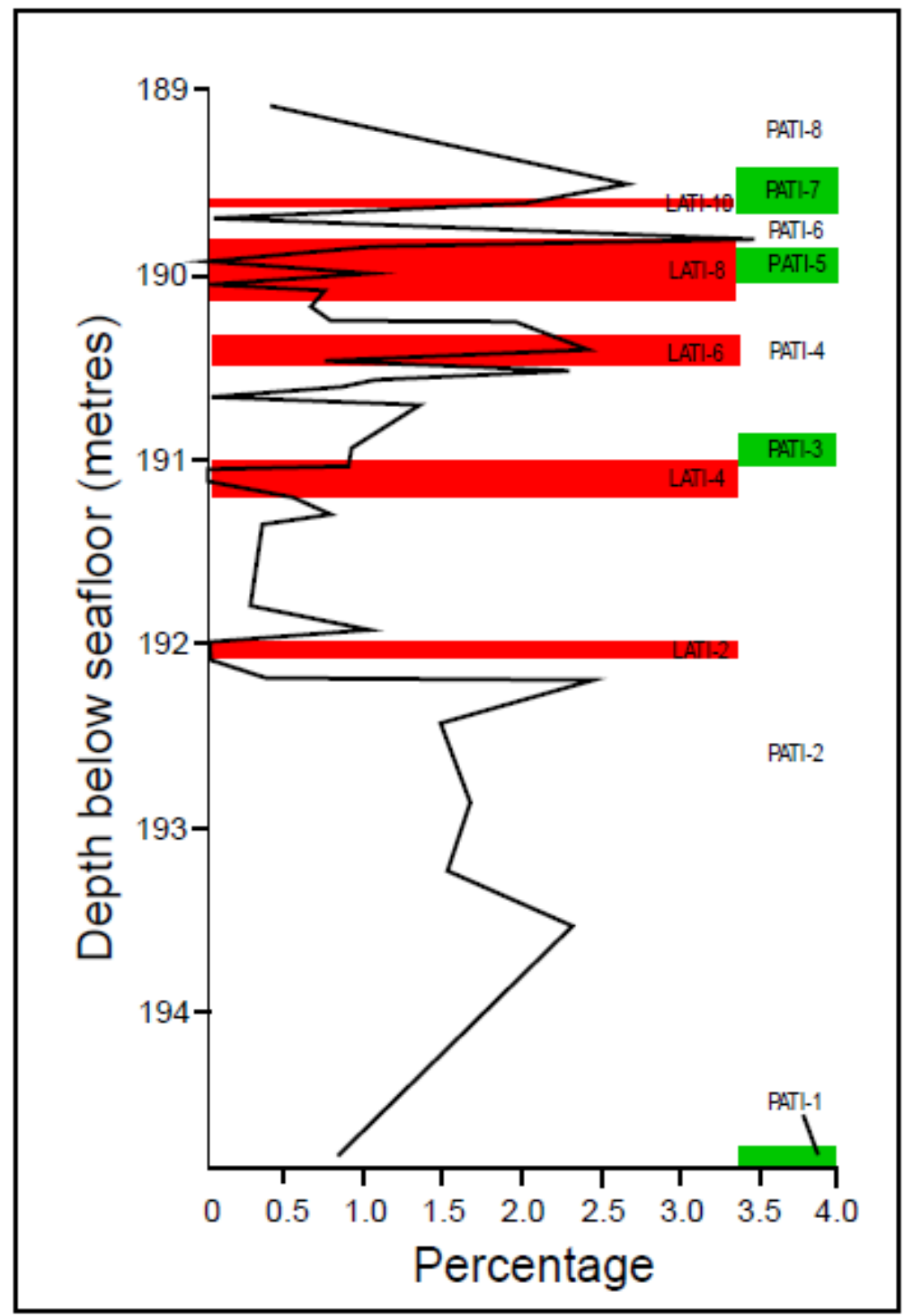

Figure 3. The percentage abundance of Anomalinoides alazanensis in the Lower Eocene at DSDP Site 401 (Bay of Biscay - NE Atlantic). Data from D'haenens et al. (2012). Red bars at left indicate marl beds $\alpha-\varepsilon$, green bars at right indicate odd-numbered peak bounded assemblage turnover intervals (PATIs).

The values for $\mathrm{CoBI}_{\mathrm{t}}$ are given in Table 1. No species contributed $>0.02$ (i.e., $>2 \%$ ) to $\mathrm{CoBI}_{\mathrm{t}}$ across all PATI or LATI boundaries. Only six species 
(Bolivina crenulata Loetterle, 1937, Bulimina virginiana Cushman, 1944, Cibicidoides eocaenus (Guembel, 1868), Globocassidulina subglobosa, Nuttallides umbonifera (Cushman, 1933), Pseudoparrella minuta Olsson, 1960) contributed $>0.1$ to $\mathrm{CoBI}_{\mathrm{t}}$ across one or more PATI or LATI boundaries. Anomalinoides alazanensis (Nuttall, 1932) contributed $\geq 0.02$ to eight of ten LATI boundaries, but to only one of seven PATI boundaries. This suggests that the proportional abundances of A. alazanensis, rather than $N$. umbonifera, buliminids, G. subglobosa and Gyroidinoides spp. can be used to distinguish marly from chalky LATIs. However, closer examination shows that $A$. alazanensis is also of limited use in distinguishing hyperthermal from nonhyperthermal communities; while a graph of the proportional abundance of $A$. alazanensis through D'haenens et al.'s (2012) section (Figure 3) shows that it was rarer in the marly LATIs 2 and 4 than in the bounding chalky LATIs 1,3 and 5, also shows that it was as abundant in the marly LATI-6 as in the chalky LATI-7. There is, therefore, no constancy in foraminiferal assemblages in the marly horizons and any ontological decision that the factors governing the development of the marls, whether palaeoclimatic or otherwise, also impacted on the foraminifera to produce identical assemblages, is unwarranted.

\section{Conclusion: Beyond Ontology}

There is in science no theory-neutral interpretation. No matter what phenomenon we observe, we interpret it in terms of our previous experience. This can lead to making unwarranted ontological decisions, as was the case of glacial-interglacial contrasts envisaged by Aksu et al. (1992), Didie and Bauch (2000), Hunt et al. (2005) and Martinez et al. (2007) and the changes in fauna between Eocene chalks and marls envisaged by D'haenens et al. (2012). This is especially misleading when either (a) an author conducts a quantitative and objective statistical analysis but interprets the results subjectively or selectively such as we showed with studies using statistical methods on Pleistocene data or (b) sees a change in one factor (e.g. palaeoclimate, lithology) and assumes that it must be reflected in another factor (e.g. faunal assemblage) as we showed in Eocene examples.Those undertaking analyses must be aware of their ontological decisions and must beware of letting them guide their interpretations. Those who seek to apply paleoecological results to neoecological work cannot as yet make conclusive or predictive statements based only upon the hypothesized similarity of biotic, lithologic or climactic past scenarios. The adoption of statistical methodology is not sufficient to provide evidence of unwarranted assumptions without knowledge of the underlying probabilistic structure while the use of objective analytical approaches such as ATI and CoBI can draw attention to many ontological decisions that authors may have adopted. 


\begin{tabular}{|c|c|c|c|c|c|c|c|c|c|c|c|c|c|c|c|c|c|}
\hline 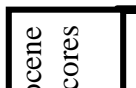 & & $\tau \tau \backslash 0 \tau-I \Perp \forall\rceil$ & & 艿 & ' & $\begin{array}{l}n \\
0 \\
0\end{array}$ & : & & & & ? & & & & & & 管 \\
\hline & & 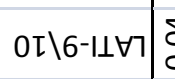 & o & ' & ' & ôे & & & $\begin{array}{l}m \\
0 \\
0\end{array}$ & & & مْ & & & & & \\
\hline & & $6 \backslash 8-1 \perp \forall 7 \mid \tilde{c}$ & ơ & ' & ' & $\begin{array}{l}n \\
0 \\
0\end{array}$ & & & סे & & J & & & & & & o a \\
\hline & & $8 \times-1177$ & \& & ' & o̊ & to & . & & ' & & శ̃ & & & & & & \\
\hline & & $\Delta$ A9-IIV7| & ¿̊. & ' & ס̊ & , & : & $\stackrel{0}{0}$ & חֶ: & & & & & & & & \\
\hline & & 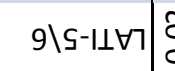 & סू. & ' & $\stackrel{8}{0}$ & $\begin{array}{l}\text { n̊ } \\
0 \\
0\end{array}$ & D. & & รี & & ' & : & & & & & \\
\hline & & $s \backslash t-I \perp \forall\rceil \mid q$ & ס & ' & ' & , & D. & & $\begin{array}{l}1 \\
0 \\
0\end{array}$ & & $\stackrel{8}{0}$ & & & ' & & & \\
\hline & & $\downarrow \backslash \varepsilon-\| \forall\rceil$ & & & $\overbrace{0}^{\infty}$ & & ?. & & $\begin{array}{l}m \\
0 \\
0\end{array}$ & & Iֶ. & & & & & & \\
\hline & & $\varepsilon \backslash Z-1 \perp \forall 7$ & & ' & Do & & : & & $\stackrel{8}{\circ}$ & & s. & & & ' & & & \\
\hline & & 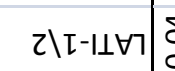 & $\begin{array}{l}\dot{0} \\
0 \\
0\end{array}$ & ' & 8) & & , & & o̊ & & ' & & & ' & & & 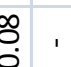 \\
\hline & & $8 \backslash<-I I \forall d$ & 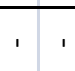 & ' & & $\begin{array}{ll} \\
0 \\
0\end{array}$ & , & & ' & & 3 & & & & & & : \\
\hline & & $\angle \backslash 9-\| \forall d$ & & סू & ' & \begin{tabular}{l} 
n. \\
\hdashline \\
$O$
\end{tabular} & ' & & ô. & & ;o & & & & $\underbrace{n}_{S}$ & & 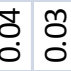 \\
\hline & 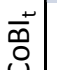 & $9 \backslash \varsigma-1 \mid \forall d$ & ' & ' & ' & $\begin{array}{ll}8 & \approx \\
0 & 0 \\
0\end{array}$ & ?. & & $\begin{array}{l}\text { Oo } \\
0\end{array}$ & . & 辛 & & & & ' & 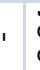 & $\begin{array}{l}\delta_{0} \\
\\
\end{array}$ \\
\hline & & $s \backslash t-I \Delta \forall d$ & ' & ' & ' & $\begin{array}{ll} \\
0 \\
0\end{array}$ & 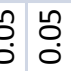 & & , & & 7 & & & & & ? & , \\
\hline & & $t \backslash \varepsilon-1 \perp \forall d \mid q$ & $\begin{array}{l}0 \\
0 \\
0\end{array}$ & & $\overbrace{0}^{\infty}$ & $\begin{array}{ll}0 & c \\
0 & c \\
0\end{array}$ & 象 & & $\begin{array}{l}\mathscr{2} \\
0 \\
0\end{array}$ & & $\because$ & & & & . & & \\
\hline & & $\varepsilon \backslash z-1 \perp \forall d$ & & ' & ס & $\left.\begin{array}{l}m \\
0 \\
0\end{array}\right]$ & D. & $\begin{array}{l}0 \\
0 \\
0\end{array}$ & $\begin{array}{l}m \\
0 \\
0\end{array}$ & & 8 & & & & ס. & & \\
\hline & & $\mid \perp \forall d$ & ' & ' & io & ב & ' & & ' & & 告 & & & & & ?ans? & 궁 \\
\hline 当 & & 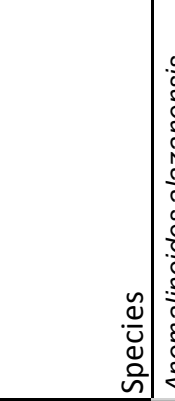 & 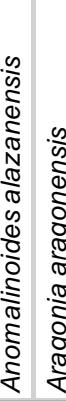 & 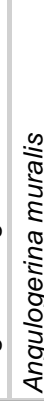 & 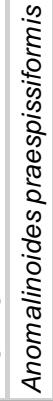 & 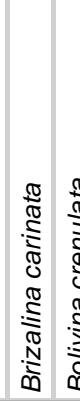 & 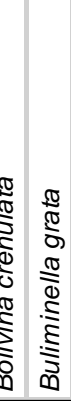 & & 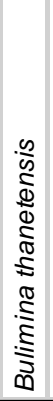 & & " & & & & & & 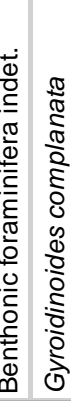 \\
\hline
\end{tabular}




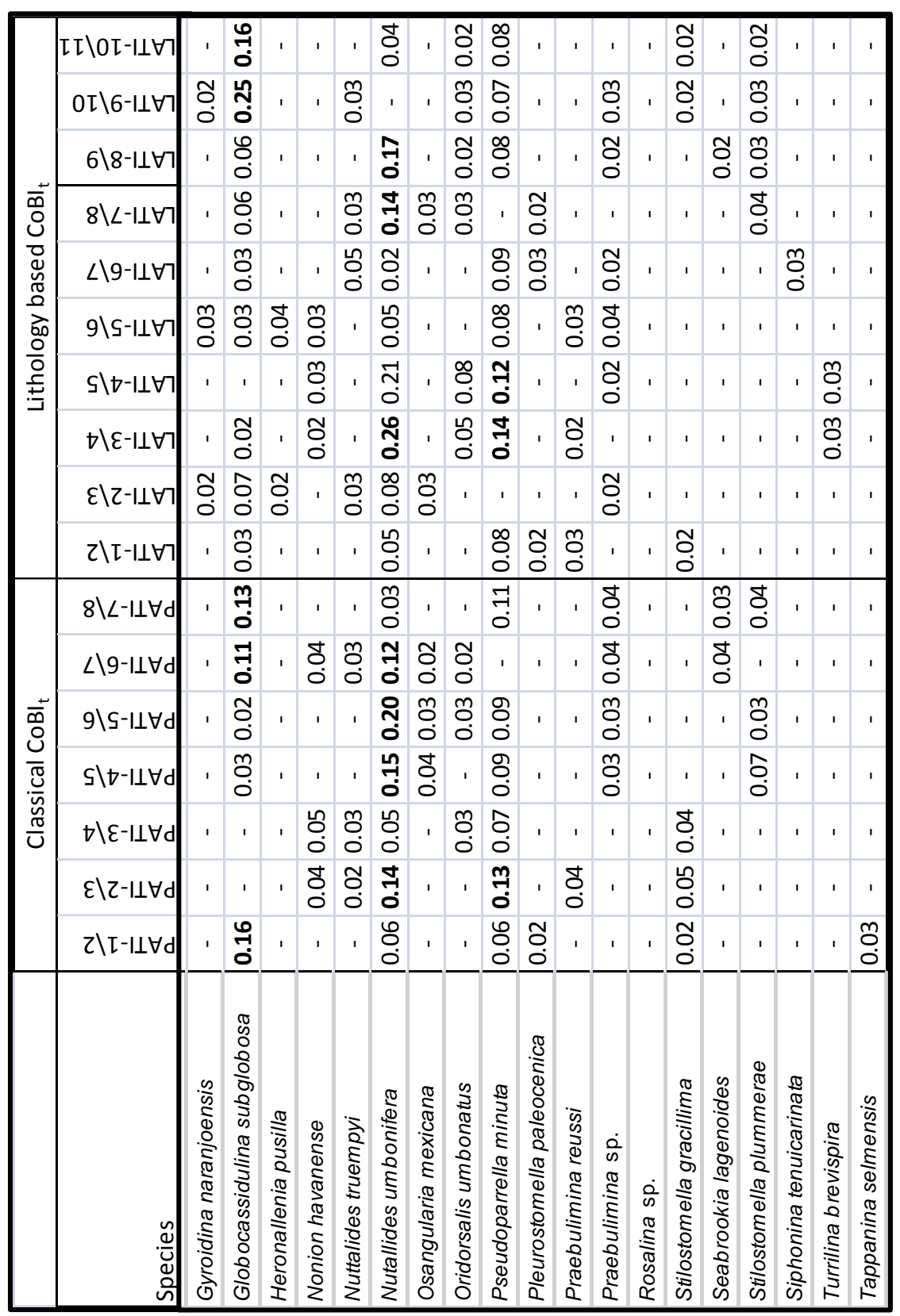




\section{Acknowledgements}

Author BW would like to express his thanks to Stuart Toddington, who originally introduced him to ontology.

\section{Literature Cited}

Aguirre, M. L., M. Donato, S. Richiano, and E. A. Farinati. 2011. Pleistocene and Holocene interglacial molluscan assemblages from Patagonian and Bonaerensian littoral (Argentina, SW Atlantic): Palaeobiodiversity and Palaeobiogeography. Palaeogeography, Palaeoclimatology, Palaeoecology 308:277-292. http://dx.doi.org/10.1016/j.palaeo.2011.05.032

Aksu, A. E., P. J. Mudie, A. de Vernal, and H. Gillespie. 1992. Ocean-atmosphere responses to climatic change in the Labrador Sea: Pleistocene plankton and pollen records. Palaeogeography, Palaeoclimatology, Palaeoecology $\quad$ 92:121-137. http://dx.doi.org/10.1016/0031-0182(92)90138-U

Alvarez Zarikian, C. A., A. Y. Stepanova, and J. Grützner. 2009. Glacial-interglacial variability in deep sea ostracod assemblage composition at IODP Site U1314 in the subpolar North Atlantic. Marine Geology 258:69-87. http://dx.doi.org/10.1016/j.margeo.2008.11.009

Astorga, G. and M. Pino. 2011. Fossil leaves from the last interglacial in Central-Southern Chile: Inferences regarding the vegetation and paleoclimate. Geological Acta 9:45-54.

Berger, W. 2008. Sea level in the late Quaternary: patterns of variation and implications. International Journal of Earth Sciences 97:1143-1150. http://dx.doi.org/10.1007/s00531-0080343-y

Böcher, J. 2012. Interglacial insects and their possible survival in Greenland during the last glacial stage. Boreas 41:644-659. http://dx.doi.org/10.1111/j.1502-3885.2012.00251.x

Buzas, M. A. and L. C. Hayek. 1998. SHE analysis for biofacies identification. Journal of Foraminiferal Research 28:233-239.

Chang, Y.-F. 2013. Environment, population dynamics and ecological synergetics. International Journal of Environment and Bioenergy 7:18-27.

Cramer, B. S., J. D. Wright, D. V. Kent, and M.-P. Aubrey. 2003. Orbital climate forcing of d13C excursions in the late Paleocene-early Eocene (chrons C24n-C25n). Paleoceanography 18:125. http://dx.doi.org/10.1029/2003PA000909

Croll, J. 1867. On the change in the obliquity of the ecliptic, its influence on the climate of the polar regions and on the level of the sea. Philosophical Magazine 33:426-445.

Croll, J. 1875. Climate and Time in Their Geological Relations: A Theory of Secular Changes of the Earth's Climate. Daldy, Isbister and Co. London, England, UK. 620 pp.

D'haenens, S., A. Bornemann, P. Stassen, and R. P. Speijer. 2012. Multiple early Eocene benthic foraminiferal assemblage and $\delta 13 \mathrm{C}$ fluctuations at DSDP Site 401 (Bay of Biscay - NE Atlantic). Marine Micropaleontology 88-89:15-35. http://dx.doi.org/10.1016/j.marmicro.2012.02.006

Didie, C. and H. A. Bauch. 2000. Species composition and glacial-interglacial variations in the ostracode fauna of the northeast Atlantic during the past 200,000 years. Marine Micropaleontology 40:105-129. http://dx.doi.org/10.1016/S0377-8398(00)00034-7

Ericson, D. B. and G. Wollin. 1956. Micropaleontological and isotopic determinations of Pleistocene climates. Micropaleontology 2:257-270. http://dx.doi.org/10.2307/1484180

Ericson, D. B. and G. Wollin. 1968. Pleistocene climates and chronology in deep-sea sediments. Science 162:1227-1234. http://dx.doi.org/10.1126/science.162.3859.1227

Evans, E. M. 2001. Cognitive and contextual factors in the emergence of diverse belief systems: creation versus evolution. Cognitive Psychology 42:217-266. http://dx.doi.org/10.1006/cogp.2001.0749

Fleming, J. R. 2006. James Croll in context: the encounter between climate dynamics and geology in the second half of the nineteenth century. History of Meteorology 3:43-54.

Fourier, J.-B.-J. 1824. Mémoire sur les temperatures du globe terrestre et des espaces planétaires. Mémoires de l'Académie Royale des Sciences de l'Institut de France 7:570-604.

Galeotti, S., S. Krishnan, M. Pagani, L. L., A. Gaudio, J. C. C. Zachos, S. Monechi, G. Morelli, and L. Lourens. 2012. Orbital chronology of Early Eocene hyperthermals from the Contessa Road 
section, central Italy. Earth and Planetary Science Letters 290:192-200. http://dx.doi.org/10.1016/j.epsl.2009.12.021

Geikie, J. 1874. The Great Ice Age and its Relation to the Antiquity of Man. W. Isbister and Co., London, England, UK. 575 pp.

Genkai-Kato, M. 2007. Regime shifts: catastrophic responses of ecosystems to human impacts. Ecological Research 22:214-219. http://dx.doi.org/10.1007/s11284-006-0304-5

Hayek, L. C. and M. A. Buzas. 1997. Surveying Natural Populations. First edition. Columbia University Press, New York, NY, USA. 562 pp.

Hayek, L. C. and B. Wilson. 2013. Quantifying assemblage turnover and species contributions at ecologic boundaries. PLoS ONE 8:e74999. http://dx.doi.org/10.1371/journal.pone.0074999

Haynes, J. R. 1981. Foraminifera. Halsted Press, John Wiley and Sons. Chichester, England, UK. $500 \mathrm{pp}$.

Higgins, J. A. and D. P. Schrag. 2006. Beyond methane: Towards a theory for the Paleocene-Eocene Thermal Maximum. Earth and Planetary Science Letters 245:523-537. http://dx.doi.org/10.1016/j.epsl.2006.03.009

Holden, A. V. and M. A. Muhamad. 1986. A graphical zoo of strange and peculiar attractors. pp. 1536. In, Chaos. Princeton University Press. A. V. Holden (Editor). Princeton, New Jersey, USA. $332 \mathrm{pp}$.

Horne, D., J. Holmes, F. Viehberg, and J. Rodriguez-Lazaro. 2013. Ostracoda as proxies for Quaternary climate change. Developments in Quaternary Science 17:376.

Hunt, G., T. M. Cronin, and K. Roy. 2005. Species-energy relationship in the deep sea: a test using the Quaternary fossil record. Ecology Letters 8:739-747. http://dx.doi.org/10.1111/j.1461$\underline{0248.2005 .00778 . \mathrm{x}}$

Kaiho, K. 1991. Global changes of Paleogene aerobic/anaerobic benthic foraminifera and deep-sea circulation. Palaeogeography, Palaeoclimatology, Palaeoecology 83:65-85. http://dx.doi.org/10.1016/0031-0182(91)90076-4

Kaiho, K. 1994. Planktonic and benthic foraminiferal extinction events during the last 100 m.y. $\begin{array}{lll}\text { Palaeogeography, } & \text { Palaeoclimatology, } & \text { Palaeoecology }\end{array}$ http://dx.doi.org/10.1016/0031-0182(94)90347-6

Katz, M. E. and K. G. Miller. 1991. Early Paleogene benthic foraminiferal assemblages and stable isotopes in the Southern Ocean. pp. 481-512. In, Proceedings of the Ocean Drilling Program, Scientific Results 114. P. F. Ciesielski and Y. Kristoffersen (Editors). 784 pp.

Kennett, J. P. and L. D. Stott. 1991. Abrupt deep-sea warming, paleoceanographic changes and benthic extinctions at the end of the Paleocene. Nature 353:225-229. http://dx.doi.org/10.1038/353225a0

Libarkin, J. C. and J. P. Kurdziel. 2006. Ontology and the teaching of Earth system science. Journal of Geoscience Education 54:408-413.

Liu, J.-X., A. Tatarenkov, T. D. Beacham, V. Gorbachev, S. Wildes, and J. C. Avise. 2011. Effects of Pleistocene climatic fluctuations on the phylogeographic and demographic histories of Pacific herring (Clupea pallasii). Molecular Ecology 20:3879-3893. http://dx.doi.org/10.1111/j.1365-294X.2011.05213.x

Lourens, L. J., A. Sluijs, D. Kroon, J. C. Zachos, E. Thomas, U. Rohl, J. Bowles, and I. Raffi. 2005. Astronomical pacing of late Palaeocene to early Eocene global warming events. Nature 435:1083-1087. http://dx.doi.org/10.1038/nature03814

Martin , R. E., E. D. Neff, G. W. Johnson, and D. E. Krantz. 1990. Biostratigraphic Expression of Sequence Boundaries in the Pleistocene: the Ericson and Wollin Zonation Revisited. pp. 229236. In, Sequence Stratigraphy as an Exploration Tool: Concepts and Practices in the Gulf Coast: 11th Annual Meeting of the Society of Economic Paleontologists and Mineralogists. G. Taylor and D. T. Dockery (Editors). 409 pp.

Martinez , J. I., G. Mora, and T. T. Barrows. 2007. Paleoceanographic conditions in the western Caribbean Sea for the last $560 \mathrm{kyr}$ as inferred from planktonic foraminifera. Marine Micropaleontology 64:177-188. http://dx.doi.org/10.1016/j.marmicro.2007.04.004 
Milankovitch, M. 1930. Mathematische Klimalehre und astronomische Theorie der Klimaschwankungen. p. 176. In, Handbuch der Klimatologie. Bornträger. W. Köppen and R. Geiger (Editors). Berlin, Germany. $176 \mathrm{pp}$.

Miller, K. G., J. V. Browning, M.-P. Aubry, B. S. Wade, M. E. Katz, A. A. Kulpecz, and J. D. Wright. 2008. Eocene Oligocene global climate and sea-level changes: St. Stephens Quarry, Alabama. Geological Society of America Bulletin 120:34-53. http://dx.doi.org/10.1130/B26105.1

Mooney, L. A., D. Knox, and C. Schacht. 2012. Understanding Social Problems Eigth Edition. Cengage Learnin. Ifford, Connecticut, USA. 608 pp.

Murray, J. W. 2006. Ecology and Applications of Benthic Foraminifera. Cambridge University Press. Cambridge, England, UK. 438 pp. http://dx.doi.org/10.1017/CBO9780511535529

Phleger, F. B., F. L. Parker, and J. F. Peirson. 1953. North Atlantic Foraminifera Reports of the Swedish Deep-Sea Expedition 7:1-122.

Roy, K., J.W. Valentine, D. Jablonski, and S.M. Kidwell. 1996. Scales of climactic variability and time averaging in Pleistocene biotas: implications for ecology and evolution. TREE 2(2): 458462. http://dx.doi.org/10.1016/0169-5347(96)10054-9

Schaffer, W. M. 1985. Order and chaos in ecological systems. Ecology 66:106. http://dx.doi.org/10.2307/1941309

Schnitker, D. 1974. West Atlantic abyssal circulation during the past 120,000 years. Nature 248:385387. http://dx.doi.org/10.1038/248385a0

Schönfeld, J., E. Alve, E. Geslin, F. Jorissen, S. Korsun, S. Spezzaferri, and members of the FOBIMO group. 2012. The FOBIMO (FOraminiferal BIo-MOnitoring) initiative-towards a standardised protocol for soft-bottom benthic foraminiferal monitoring studies. Marine Micropaleontology 94-95:1-13. http://dx.doi.org/10.1016/j.marmicro.2012.06.001

Segota, T. 1967. Paleotemperature changes in the Upper and Middle Pleistocene. Eiszeitalter und Gegenwart 18:127-141.

Sen Gupta, B. K., T. J. Temples, and M. D. G. Dallmeyer. 1982. Late Quaternary benthic foraminifera of the Grenada Basin: Stratigraphy and Paleoceanography. Marine Micropaleontology 7:297-309. http://dx.doi.org/10.1016/0377-8398(82)90007-X

Shipboard Scientific Party. 2004. Site 1259. Proceedings of the Ocean Drilling Program, Initial Reports 207: 1-110.

Sluijs, A., G. J. Bowen, H. Brinkhuis, L. J. Lourens, and E. Thomas. 2007. The Paleocene-Eocene Thermal Maximum super greenhouse: biotic and geochemical signatures, age models and mechanisms of global change. pp. 323-350. In, Deep-Time Perspectives on Climate Change: Marrying the Signal from Computer Models and Biological Proxies. M. Williams, A. M. Haywood, F. J. Gregory, and D. N. Schmidt (Editors). The Micropalaeontological Society. London, Egland, UK. 592 pp.

Smart, C. W. 2003. Environmental applications of deep-sea benthic foraminifera. pp. 14-58. In, S. K. Haslett (Editor). Quaternary Environmental Micropalaeontology. Hodder Headline Group. London, England, UK. 340 pp.

Sowa, J. F. 2010. The role of logic and ontology in language and reasoning. pp. 231-263 In, Theory and Applications of Ontology: Philosophical Perspectives. Poli, R. and J. Seibt (Editors). Springer. Berlin, Germany. 422 pp. http://dx.doi.org/10.1007/978-90-481-8845-1_11

Stap, L., L. Lourens, A. v. Dijk, S. Schouten, and E. Thomas. 2010. Coherent pattern and timing of the carbon isotope excursion and warming during Eocene Thermal Maximum 2 as recorded in planktic and benthic foraminifera. Geochemistry, Geophysics, Geosystems 11:1-10. http://dx.doi.org/10.1029/2010GC003097

Streeter, S. S. 1973. Bottom water and benthonic foraminifera in the North Atlantic-Glacialinterglacial contrasts. Quaternary Research 3:141-141. http://dx.doi.org/10.1016/00335894(73)90059-8

Streeter, S. S. and S. A. Lavery. 1982. Holocene and latest glacial benthic foraminifera from the slope and rise off eastern North America. Geological Society of America Bulletin 93:190-199. http://dx.doi.org/10.1130/0016-7606(1982)93<190:HALGBF>2.0.CO;2 
Takeda, K. and K. Kaiho. 2007. Faunal turnovers in central Pacific benthic foraminifera during the Paleocene-Eocene thermal maximum. Palaeogeography, Palaeoclimatology, Palaeoecology 251:175-197. http://dx.doi.org/10.1016/j.palaeo.2007.02.026

Thomas, D. J., T. J. Bralower, and J. C. Zachos. 1999. New evidence for subtropical warming during the late Paleocene thermal maximum: stable isotopes from Deep Sea Drilling Project Site 527, Walvis Rigde. Paleoceanography 14:561-570. http://dx.doi.org/10.1029/1999PA900031

Thomas, E. 1992. Cenozoic deep-sea circulation: Evidence from deep-sea benthic foraminifera. Antarctic Research Series 56:141-165. http://dx.doi.org/10.1029/AR056p0141

Thomas, E. and N. J. Shackleton. 1996. The Paleocene-Eocene benthic foraminiferal extinction and stable isotope anomalies. pp. 401-441. In, Correlation of the Early Paleogene in Northwest Europe. Geological Society Special Publication 101. R. W. O. B. Knox, R. Corfield, and R. E. Dunay (Editors). $300 \mathrm{pp}$.

Thomas, E. and J. C. Zachos. 2000. Was the late Paleocene thermal maximum a unique event? . Geologiska foreningens $i$ Stockholm Forhand (Transactions of the Geological Society of Stockholm) 122:169-170.

Wilson, B. 2008. Late Quaternary benthonic foraminifera in a bathyal core from the Leeward Islands, Lesser Antilles, NE Caribbean Sea. Journal of Micropalaeontology 27:177-188. http://dx.doi.org/10.1144/jm.27.2.177

Wilson, B. 2011. Alpha and beta diversities of Late Quaternary bathyal benthonic foraminiferal communities in the NE Caribbean Sea. Journal of Foraminiferal Research 41:40-47. http://dx.doi.org/10.2113/gsjfr.41.1.33

Wilson, B. 2012. Biogeography and ecostratigraphy of Late Quaternary planktonic foraminiferal taphocoenoses in the Leeward Islands, Lesser Antilles, NE Caribbean Sea. Marine Micropaleontology 86-87:1-12. http://dx.doi.org/10.1016/j.marmicro.2011.12.002

Wilson, B. 2013. Ecostratigraphic regime shift during Late quaternary Marine Isotope Stages 8-9 in Santaren Channel, western tropical Atlantic Ocean: benthonic foraminiferal evidence from ODP Hole 1006A. Journal of Foraminiferal Research 43:143-153. http://dx.doi.org/10.2113/gsjfr.43.2.143

Wilson, B. 2014. Abundance Biozones and Community Structures in the Upper Quaternary of ODP Hole 994C (Blake Ridge, western Atlantic Ocean) compared with Marine Isotope Stages, Glacial Cycles and Terminations. Journal of Foraminiferal Research 44:28-39. http://dx.doi.org/10.2113/gsjfr.44.1.28

Wing, S. L. and G. J. Harrington. 2001. Floral response to rapid warming in the earliest Eocene and implications for concurrent faunal change Paleobiology 27:539-563. http://dx.doi.org/10.1666/0094-8373(2001)027<0539:FRTRWI>2.0.CO;2

Zachos, J. C., S. M. Bohaty, C. N. John, H. McCarren, D. C. Kelly, and T. Nielsen. 2007. The Palaeocene-Eocene carbon isotope excursion: constraints from individual shell planktonic foraminifer records. Philosophical Transactions of the Royal Society 365:1829-1842. http://dx.doi.org/10.1098/rsta.2007.2045

\section{Appendix 1}

Hayek and Wilson (2013) presented two types of analysis. The first, in which species' proportional abundances alone are considered, is here termed Classical Analysis of ATI. The second, in which both species' proportional abundances and lithology are considered, is here termed Lithological Analysis of ATI.

In Classical Analysis of ATI, the ATI is initially calculated for each pair of adjacent samples in a time series. It is defined as 


$$
A T I=\sum\left|p_{i 2}-p_{i 1}\right|
$$

in which $\mathrm{p}_{\mathrm{i} 1}$ and $\mathrm{p}_{\mathrm{i} 2}$ are the proportional abundances of the $i$ th species, $\mathrm{i}=1, \ldots$, $\mathrm{s}$, in the lower and upper samples. The summation sign was inadvertently omitted in the original publication of Hayek and Wilson (2013).). This assemblage turnover index between samples is denoted as ATIs. The mean $\bar{x}$ and standard deviation $\sigma$ are calculated for the series of $\mathrm{ATI}_{\mathrm{s}}$ and for Classical Analysis of ATI are used to determine control charts and values for which $A T I_{s}>(\bar{x}+\sigma)$. These peaks in $\mathrm{ATI}_{\mathrm{s}}$ indicate the positions of relative major assemblage turnovers (Hayek and Wilson, 2013), and are used to divide the succession into peak-bounded ATI $_{\mathrm{S}}$ (PATI-) intervals. These intervals were numbered, commencing from PATI-1 for the oldest. PATI-1 and the uppermost PATI are of necessity incomplete, their lower and upper boundaries respectively not being bounded by peaks in $\mathrm{ATI}_{\mathrm{s}}$.

In Lithological Analysis of ATI, for comparison, the succession is divided into intervals defined by lithology, here termed LATI intervals, which are numbered, commencing from LATI-1 for the oldest. The positions of the peaks in $\mathrm{ATI}_{\mathrm{s}}$ (i.e., the PATI boundaries) are compared with the LATI boundaries.

Hayek and Wilson (2013) presented also a thorough conditioned-onboundary index $\mathrm{CoBI}_{\mathrm{t}}$ that assesses which species contributed most to the ATI at PATI and LATI boundaries. That is, $\mathrm{CoBI}_{\mathrm{t}}$ presents the proportion that each species within an assemblage contributed to the turnover across the PATI or LATI boundary. For each species at any boundary

$$
C o B I=\left|p_{i 2}-p_{i 1}\right| / A T I
$$

where $\mathrm{p}_{\mathrm{ij}}, \mathrm{j}=1,2$ are the $i$ th species proportions in the PATIs or LATIs on either side of the selected boundary of interest and at which the ATI is calculated. In $\mathrm{CoBI}_{\mathrm{t}}$, then, the ATI is denoted as $\mathrm{ATI}_{\mathrm{t}}$ and is calculated between the values in two complete PATIs or LATIs. The value of $\mathrm{ATI}_{t}$ is substituted into equation (2), as are $\mathrm{p}_{\mathrm{i} 1}$ and $\mathrm{p}_{\mathrm{i} 2}$, the proportional abundance of the $i$ th species in intervals (PATIs or LATIs) being compared. The proportional contribution of each species to the value of $\mathrm{ATI}_{t}$ is assessed from the vector of thorough CoBI for each PATI or LATI boundary. 